\title{
THE ROLE OF BRAND EQUITY AND BRAND AWARENESS IN ATTRACTING OF NEW GRADUATED ENGINEERS IN CONSTRUCTION SECTOR IN TURKEY
}

\author{
Kader OSKAYBAŞ ${ }^{1}$, Asil Selman GÜMRÜKÇÜ²
}

\section{ABSTRACT}

One of the conditions for sustainability of a company is to strategically attract and retain young personnel in accordance with the market rate which have received required education, who believe in the goals and aspirations of the organization and are dedicated to ensuring the success of the organization To identify these young brains and recruit them to the organization for long terms is a very difficult task especially in today's communication and fast consumer society. The aim of this study is to investigate whether brand awareness/brand equity influences the attraction of new graduated and university students in the Turkish construction sector.

Key words: Company preference, brand awareness, young graduated engineering faculties personnel

\footnotetext{
${ }^{1}$ Yrd.Doç.Dr, Maltepe Üniversitesi, iïBF, İşletme Bölümü, kaderkara@maltepe.edu.tr

2 Asil Selman GÜMRÜKÇÜ, agumrukcu@enka.com
} 


\section{INTRODUCTION}

One of the task for the managers for sustainability of their companies is to handover their positions to talented younger personnel when the time comes. Especially, in some occupations attracting and retaining innovative young brains in today's comparative market conditions has become a challenge for many companies.

There are many researches on the attracting factors on customer choice's which compares the similar product's price, capabilities, brand awareness etc, however there are limited researches regarding the factors that influence the employees decisions during the first stage of recruitment or how firms can systematically impact those factors (Barber, 1998). There is some evidence that brand equity and brand awareness (Cable \& Turban, 2001; Collins \& Stevens, 2002) affects job seekers' attraction to and intentions to apply to organizations.

According to Collins \& Stevens, (2002) there is some evidence that recruitment activities affect job seekers' perceptions of employment brands, very little attention has been given to the potential effects of organizational brand building activities (e.g. corporate marketing and advertising). Barber (1998) proposed that there might be spillover effects of organizational marketing on job seekers' perceptions of the organization as an employer.

However, these factors have not been thoroughly researched in Turkey yet. In this respect, the aim of this study is to investigate whether brand awareness/brand equity influences the attraction of university students in the Turkish construction sector.

\section{Brand Equity and Brand Awareness}

An organization's efforts to recruit job seekers are similar in many ways to the organization's efforts to attract consumers to purchase their products or services (Cable \& Turban, 2001). Specifically, job seekers and consumers both develop positive or negative perceptions about companies and jobs based on their exposure to messages communicated by an organization (Collins \& Stevens, 2002).

Aaker (1996) defined brand equity as the positive or negative effects that the brand has on consumers' preferences and purchasing decisions of a product or service marketed under this brand.

According to Keller's (1991) definition, brand equity consists of two independent factors. The first dimension of brand equity is brand awareness, which represents the strength of a consumer's memory record for the brand (Keller, 1991). Greater awareness increases consumers' ability to identify a brand and the likelihood that the brand will be included in the consideration set (Aaker, 1996; Rossiter \& Percy, 1987). The second dimension of brand equity is brand associations, defined as the memory nodes linked to the corresponding brand node in consumer's memory, which contain the meaning that the brand has for consumers (Keller, 1991). Aaker $(1991,1996)$ argued that brand associations facilitate the process of consumer choice -consumers are more likely to choose those brands for which they hold strong, positive associations. There are two key categories of associations - attributes (specific beliefs about the product, service, or organization) and attitudes (general feelings toward the product, service, or organization).

Based on the consumer brand equity literature Collins and Stevens (2002) identify two dimensions of employment brand equity such as awareness and associations. They define awareness as the level of familiarity job seekers hold with an organization. As with consumers, awareness of a company increases the likelihood that it will be part of the final decision set when job seekers identify premium employment opportunities. As with the brand equity literature discussed above, Collins and Stevens (2002) argue that brand associations consist of both attitudes and perceived attributes. They define attitudes as the level of general positive feelings that job seekers hold toward an organization, whereas perceived attributes are job seekers' beliefs about specific aspects of the job and the organization's work environment of the organization.

The term employer branding can be defined as "the package of functional, economical, and psychological benefits provided by employment, and identified with the employing company" (Amber and Barrow 1996, p 186). Just as consumers depend on brands differentiate the products, employer branding is used by potential employees to differentiate between employers and assist their decision making (Collins and Stevens).

The relation between the brand and the consumer can be considered as a pact. The customer is loyal and trustful while the brand guarantees a consistent quality and pricing (Esch F.-R. ,2008). What is questionable is whether a brand has the same effect on current and potential employees. Hence the question is: Does a brand also influence the employer attractiveness? (Keller, K. L. 2003)

Research has suggested that media visibility, advertising and marketing activities affect brand equity. Advertising is positively related to consumers' awareness, attitudes (Cobb-Walgren et al., 1995), and associations (Boulding et al., 1994). Marketing activities such as social responsibility projects and differentiation positively affect corporate brand equity (e.g. Upshaw, 1995; Dowling, 2001). 
Previous research on brand awareness has provided evidence that job seeker's perceptions of an organization as employer are positively related to job seeker's intention to apply (e.g. Collins \& Stevens, 2002; Gatewood et al., 1993).

As observable above, these concepts have been introduced in the last 25 years to the business world, and they are very recent and are still not prevalent in Turkey. The importance of branding is on the rise in Turkey and, companies are gaining momentum towards this investment.

In the world there are different types of researches done to identify the brand equity. Recently in 2013 a research was conducted in Turkey by a British consulting company "Brand Finance" to identify "Turkey's Most Valuable Brands". According to the results, the most valuable brand in Turkey was Turkish Telecom 2,380 billion dollars.

Table 1: Year 2013Turkey's Most Valuable Brands according to "Brand Finance" research

\begin{tabular}{|c|c|c|c|c|}
\hline $\begin{array}{l}\text { Ranking } \\
2013\end{array}$ & Brand Name & \multicolumn{3}{|c|}{$\begin{array}{l}\text { Brand Value } 2013 \\
\text { (M usd) }\end{array}$} \\
\hline 1 & TURKTELEKOM & $\$$ & 2,380 & \\
\hline 2 & AKBANK & $\$$ & 2,121 & \\
\hline 3 & iş BANKASI & $\$$ & 2,061 & \\
\hline 4 & TURK HAVA YOLLARI & $\$$ & 1,800 & \\
\hline 5 & GARANTI BANKASI & $\$$ & 1,579 & \\
\hline 6 & TURKCELL & $\$$ & 1,497 & \\
\hline 7 & ARÇELIK & $\$$ & 1,455 & \\
\hline 8 & BiM & $\$$ & 1,391 & \\
\hline 9 & ANADOLU EFES & $\$$ & 1,272 & \\
\hline 10 & YAPI KREDI BANKASI & $\$$ & 1,117 & \\
\hline 11 & PETROL OFISI & $\$$ & 1,075 & \\
\hline 12 & HALK BANKASI & $\$$ & 1,063 & \\
\hline 13 & FORD OTOMOTIV & $\$$ & 955 & \\
\hline 14 & VAKIFBANK & $\$$ & 829 & \\
\hline 15 & ENKA & $\$$ & 731 & \\
\hline 16 & MiGROS & $\$$ & 680 & \\
\hline 17 & OPET & $\$$ & 674 & \\
\hline 18 & ÜLKER BISKÜVi & $\$$ & 652 & \\
\hline 19 & VESTEL ELEKTRONIK & $\$$ & 412 & \\
\hline 20 & ŞIŞE CAM & $\$$ & 405 & \\
\hline
\end{tabular}

With the growing economy, the importance of brand equity and investment on branding is increasing in Turkey. However, Turkish companies still have considerably less brand equities compared with the market values of the companies.

\subsection{Brand Equity and Brand Awareness in Construction Industry in Turkey}

The Turkish construction and contracting industry is one of the leading industries in Turkey. Every year several Turkish construction/contracting companies ranking in the Top 250 international contractors lists (ENR List http://enr.construction.com/ toplists/top-global-contractors/001-250.asp); which makes the Turkish construction/contracting industry the world's in top 5 countries list. Not only internationally abroad, also as a emerging country in Turkey, construction companies has a remarkable role for Turkish economy. However comparing with the economical size and significance of construction industry in Turkey, construction companies investment's on brand awareness are very minor. This is also not because the companies oversee this value but rather because this is the nature of industry. As a result, the construction companies' effort to administer employer branding is very minor compared to employer branding of finance or production companies.

Major domestic construction companies which work inside Turkey are mainly build and marketing the residential/ office buildings and the brand name awareness plays a serious role for their marketing activities. Therefore recently the brand equity and brand awareness importance have been recognized by these companies. Promotions and advertising during marketing activities of these major domestic construction companies increases popularity of their brand name and brand awareness inside the country. 
For the international contractors which are focused on foreign markets, brand awareness in Turkey plays a role mainly for attracting talented younger personnel for its international Projects. As of today, these companies have not invested for brand awareness owing to reasons such as:

i) promoting or improving brand awraness is both expensive and time consuming

ii) domestic brand awareness has no/ or minor influence on international contracts.

iii) the Construction market had not boomed as it has today, there were not many opportunities for high qualified talented personnel in Turkey.

iv) required high qualified personnel for projects abroad were easily attracted with the salary benefits offered in foreign currency, without any effect of the brand name of the companies.

However, in recent years the conditions have changed and international contractors are facing challenges. They are still attracting the new graduated personnel, but sometimes have difficulties retaining qualified ones. This is a clear indication that to attain sustainable growth, international contractors need to adopt a new strategy in attracting and retaining high qualified personnel in the near future.

\subsubsection{Profile of Engineers in Construction Business in Turkey}

For construction industry the main requirement as human capital are white color staff which are engineers, technician and supervisors and blue collar staff which are Forman, different trade labors operators. The main sources for white color staff are the Universities.

In Turkey over 120 universities have Engineering Faculties and with 75.000 engineer graduates every year. Even though this number seems high and sufficient when we compare it can be observed that it is not in the required level. In EU the ratio of engineers in the working population is at an average of 2.14\% (Sak Guven, Radikal 2013 ). This ratio varies within the EU, as such average in Germany is higher at 3\% and in Spain less than 1,5\%.The same figure for one of the most developed Asian countries, namely North Korea is at $3 \%$ similar to Germany. The ratio of engineers in the working population for Turkey is $0.94 \%$.

Notwithstanding the fact that the population of Turkey, Germany and Korea are at the same level (75 000 000- 80000000 persons) and that the number of annually graduated engineers are similar (75 000 graduates/annually) the ratio of engineers in the working population in Turkey is 3 times less than Germany /Korea (0,94\% vs 3\%).

Research indicates that this discrepancy is due to graduate engineers in Turkey not being able to find jobs to match their own professions, and also because graduate engineers prefer to work in other jobs rather than their own professions.

If we look deep in construction industry, in Turkey every year 10.800 civil engineering students are admitted to 279 different education programmes, in 104 universities. Besides civil engineers, over 25.000 other engineers such as mechanical, electrical engineers are graduating every year who mainly seek jobs in the construction sector.

\section{Research}

The recent researches prove that even though salary is a significant factor in company selections, employee engagement is not all about financial compensation. There are many non-monetary programs employers can adopt to help improve the morale and productivity.

In 2013, US based HR services and staffing company Randstad, conducted a research on 3,282 adults aged 18 and older who are currently employed full time in US. Nearly all of those polled (96\%) mentioned the importance of brand equity and reported that it would be important for their new company to have a good reputation among its employees, while nearly as many (86\%) say it is important to have a good reputation in their community. Additionally, $68 \%$ of respondents believe their new company should invest in corporate social responsibility efforts.

On another research by Ernesto Dal B'o Frederico Finan Mart'ın A. Rossi ,shows that offering higher wages attracts individuals with higher previous earnings, and who have both higher IQ and more desirable personality traits, as measured by public service motivation tests. Overall these findings highlight the importance of financial incentives in not only attracting qualified individuals but also inducing them to work in hard-to-fill positions.

A further research by Chandler McLeod (2007) with 2,186 job seekers and 436 HR professionals across Australia indicated a difference between what job seekers wanted and what HR professionals thought made their organization attractive to prospective employees The ten most attractive employer attributes listed by job seekers were:

- $\quad$ an employer's reputation for looking after and valuing employees 
- challenging and/or engaging work

- training and development

- a fun, positive and vibrant working environment

- career development and progression

- an attractive salary or financial incentives

- recognition of performance

- understanding the importance of family or life outside work

- fair pay for a fair day's work

- definitive and strong company values.

The most apparent differences were that employers ranked recognizable company brand, challenging and engaging work, and strong company values much higher than did employees. Employees ranked a vibrant and positive work environment, attractive salary and other financial incentives, performance rewards and recognition, fair pay for a fair day's work and a manager they liked much higher than employers did.

On a further note, no similar researches which identify attractive employer attributes by job seekers were found in Turkey which can be referenced in this Project.

Therefore, in the questionnaire which was prepared for this project, the main attraction factors were kept similar to factors referred to above international researches. These were: Salary \& Economical benefits, Working Location, Title, Brand Awareness/Brand Equity, Career planning.

\subsection{Methods}

Participants for the study were selected from engineering faculties of Universities in Istanbul. The questionnaires were completed by a total of 130 University Engineering Faculty students in from YTU (Yıldız Technical University), ITU (Istanbul Technical University) and BU (Bosphorous University) in Istanbul during the period 10 April 2014-03 May 2014.

The tool used for the research method was a questionnaire (refer to annex 1). A questionnaire (refer to appendix 1) which was containing 9 (nine) questions, prepared used as a data collection method for the research.

Questions No.1-No.4 were questioned individual's aims and knowledge for job selection. Questions No.4-No.9 were related with the individual's selection criteria for their first job application and influence of brand awareness. Main findings were analyzed with the results of these 5 questions.

\subsection{Result Findings and Discussion}

The collected data was grouped and analyzed based on percentages. Along with brand awareness; Salary, Work location, Offered work title, Offered contract duration and Offered career plan were the other influences included in the questionnaire.

\subsubsection{Statistical Data}

Under question 1 and 2 of the questionnaire, respondents were asked to indicate if they possess enough information about their future works possibilities and options and where this information is obtained. The results indicated that $60 \%$ of the respondents, in their own opinions, possess adequate information on future works possibilities and $44 \%$ of the respondents obtained this information from Universities.

Results provided by the respondents for question 1 and 2 are reflected below.

Q1 -Do you have enough information for your future possible work options conditions?

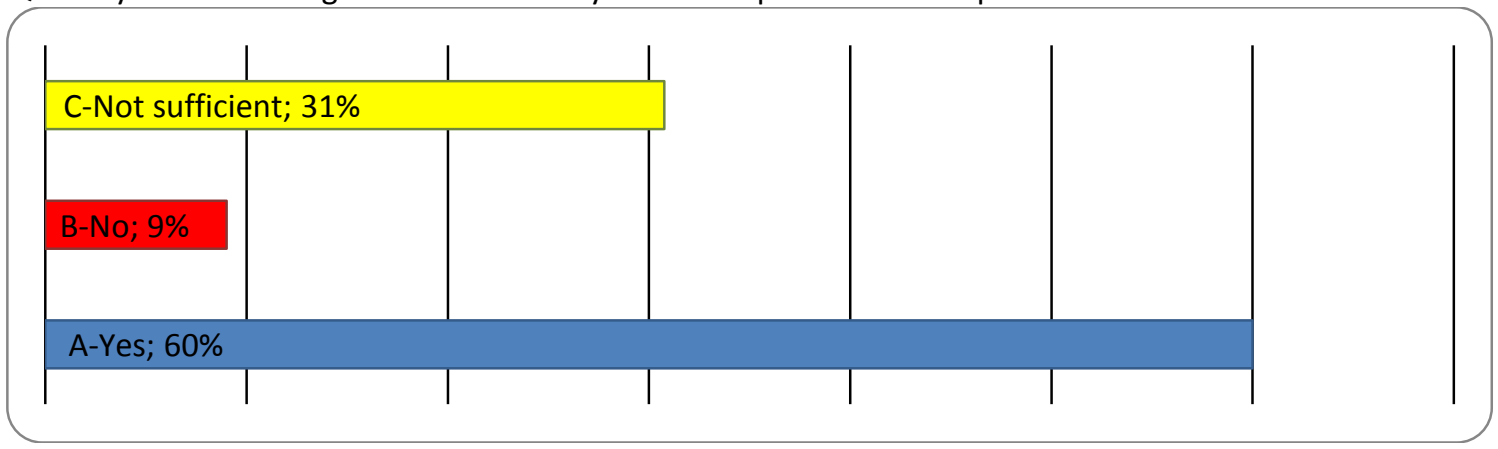

Figure no 1: Answer for Question no 1 in the questionnaire 
Q2-From where is this information obtained?

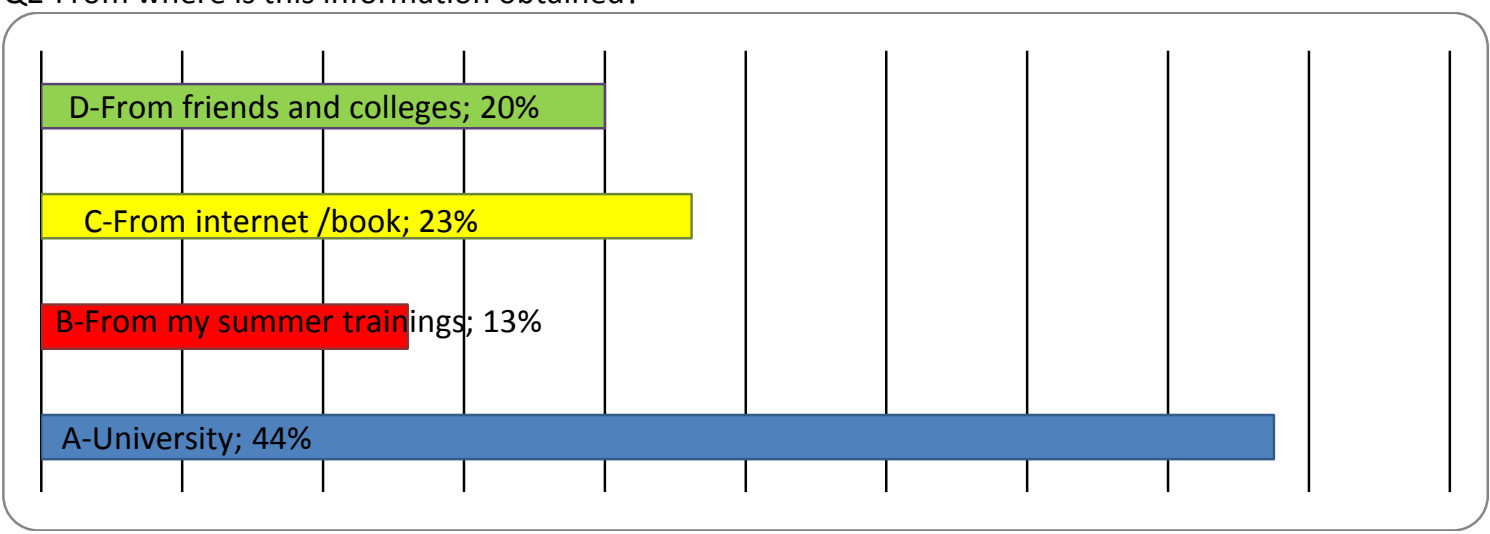

Figure no 2: Answer for Question no 2 in the questionnaire

The aim of the next question (Q3) was to understand which type of jobs the respondents prefer. The results indicated that $68 \%$ prefer their jobs to be in design engineering and $17 \%$ prefer marketing and finance. Results provided by the respondents for question 3 is reflected below.

Q3-What type of work do you prefer?

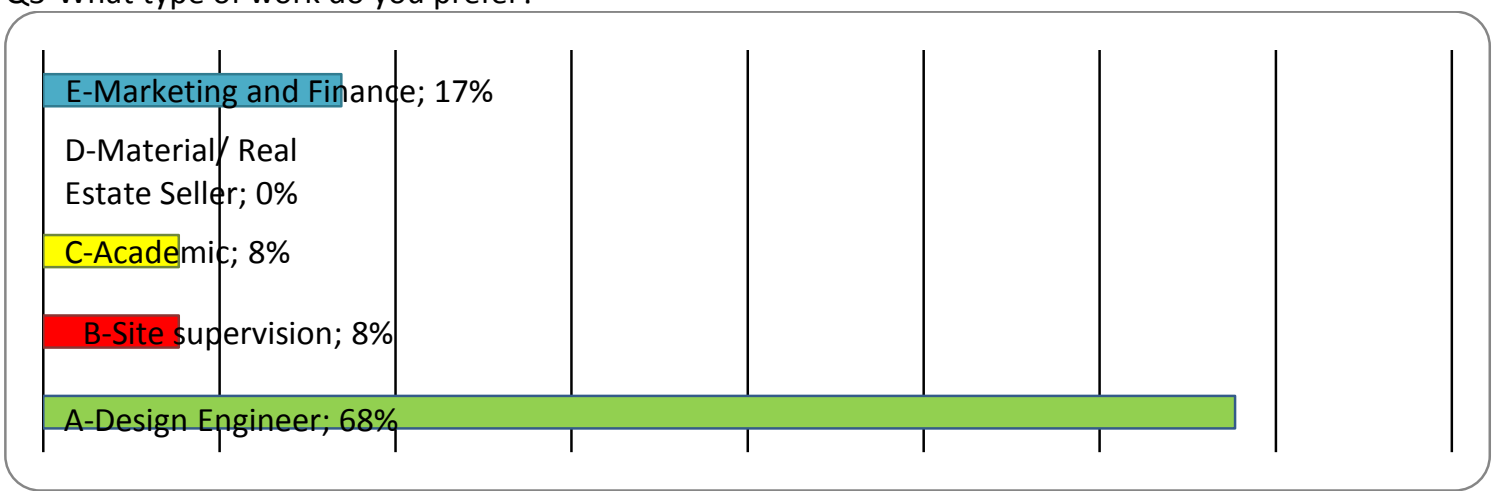

Figure no 3: Answer for Question no 3 in the questionnaire

Under question 4 of the questionnaire, factor which plays a major role in the students' first job selection was questioned. $40 \%$ of the respondents indicated that future career planning is the first factor considered whereas salary was only considered a first factor by $22 \%$ of respondents.

Q4-Which of the listed conditions affect the major role on your first job selection?

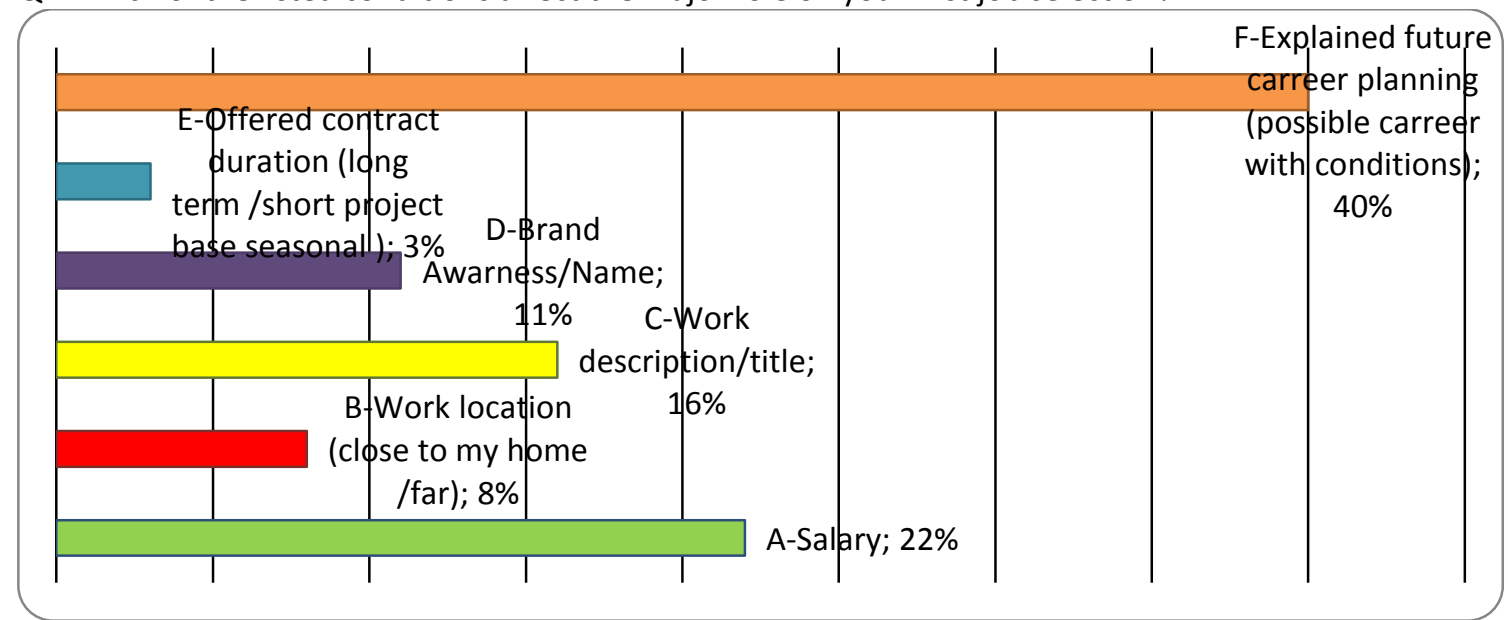

Figure no 4: Answer for Question no 4 in the questionnaire

Under question 5 , major $2^{\text {nd }}$ and $3^{\text {rd }}$ factors in the students first job selection was questioned.

Responses were evaluated together with questions 4\&5. Accordingly, salary was indicated by respondents as the major factor with $24 \%$ followed by future career planning $22 \%$, work description /work title $22 \%$ respectively. 


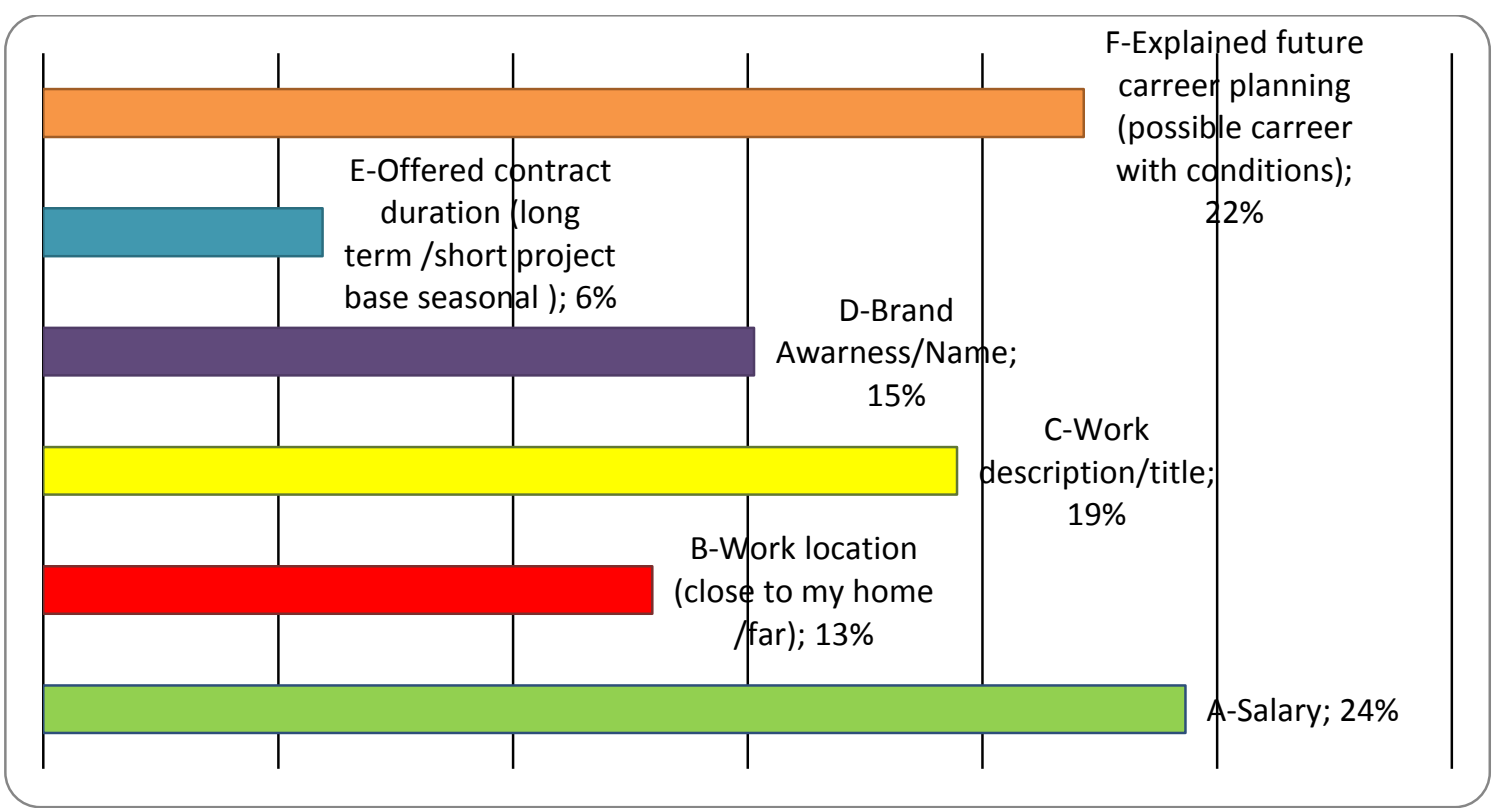

Figure no 5: Combined Answers for Question no 4\&5 in the questionnaire

Results for these 2 questions showed that only $15 \%$ of respondents considered brand awareness/name as one of the top 3 main factors for their first job selection. According to these results, $15 \%$ of respondents who considered brand awareness/name were ranked on $4^{\text {th }}$ place after salary(24\%), career planning (22\%), work description /title (19\%).

Additionally, companies which offer long term career possibilities are of significant importance to university students and has a similar priority to salary benefits.

Under question no 6 and no 7, respondents revealed that work location (34\%) and contract duration (28\%) for the job are considered the items which students regard as having the least effect on their first job selections.

Answers to the question 8 and 9: "If you believe that your decision might change after 5 years experience which of the previous conditions would affect a major/minor role on your first decision for job selection " revealed that effect of salary increased from $22 \%$ to $40 \%$ with respect to question No. 4 where first factor was asked.

Even the effect of work location decreased from $44 \%$ to $31 \%$ as the least effective factor. This decrease shows that with experience individuals become more selective for work locations.

\section{Conclusion}

During the research for this project, the availability of previous studies on the topics of brand equity, brand awareness and their effects on Turkish markets were insufficient. The available resources in Turkey were focused on company rankings based on brand value - brand awareness. Additionally, there was some research on the effects of brand awareness on consumers in Turkey, but no research was available for the effects on employees.

In order for corporate companies to evaluate the importance of brand awareness and brand equity on employee attraction, the number of researches needs to be increased in Turkey.

The result of this study suggests that contrary to previous indications and researches in other countries on the similar topic "effect of brand awareness on employee attraction",

- the effects of brand awareness on employee attraction in Turkey are low in general.

- In Turkish construction industry the companies with little or no corporate brand awareness still can be attractive for new graduated engineers with offering higher salary.

- Two HR management topics; "Career planning" and "job title" are come forward as the result of the research on employee attraction in Turkey. This proves that young engineers pay attention for structured career planning, which means they want to know, when, how and what he will gain as a result of his commitment to the company. Companies can prepare a career planning for their organizations to become more attractive for young engineers.

- Salary is the main factor on employee attraction in Turkey. Much higher effect on attraction of employees than brand equity/brand awareness in Turkey similar to other countries. 
As a final note; in future more research in Turkey needs to focus on the effects of brand awareness on employee attracting.

\section{References}

Aaker, D.A. (1991). Managing Brand Equity. New York: The Free Press

Aaker, D.A. (1996). Building Strong Brands. New York: The Free Press.

Ambler, T. \& Barrow, S. (1996). The employer brand. Journal of Brand Management, 4, 185-206.

Barber, A. E. (1998). Recruiting employees: Individual and organizational perspectives. Thousand Oaks, CA: Sage.

Boulding, W., Kalra A., Staelin R. and Zeithaml V. (1994) A dynamic process model of service quality: From expectations to behavior intentions, Journal of Marketing Research 30(February).

Brand Finance, http://brandirectory.com/league_tables/table/turkey-100-2013

Cable, D.M. \& Turban, D.B. (2001). Establishing the dimensions, sources and value of job seekers' employee knowledge during recruitment. Research in Personnel and Human Resources Management, .

Cobb-Walgren, C. J., Ruble C. A., \& Donthu N. (1995) Brand equity, brand preference, and purchase intent. Journal of Advertising 24: 25-40.

Collins, J. C. \& Stevens, K. C. (2002). The Relationship between early recruitment-related activities and the application decision of new labour-market entrants: a brand equity approach to recruitment. Journal of Applied Psychology, 87 (6),.

Dowling, G.R.(2001),CreatingCorporateReputationsıIdentitylmage, and Performance, Oxford University Press, Oxford.

Esch, FranzRudolf (2008), Strategie und Technik der Markenführung (3. ed.). München: Vahlen

Gatewood ,R.D.,Gowan,M.A.,and Lautenshlager,G.J (1993) Corporate Image Recruitment Image, and Initial job choice decisions, Academy of Management Journal vol 36 no 2

Keller, Kevin Lane . (1991). Conceptualizing, measuring, and managing customer-based brand equity. Journal of Marketing.

Keller, Kevin Lane, 2003. Building Customer-Based Brand Equity: A Blueprint For Creating Strong Brands. Marketing Science Institute Working Paper Series 2001, Report No. 01-07.

Rossiter \& Percy, (1987), Advertising and promotion management McGrawHill New York, N.Y.

Sak Guven, Radikal , 15 January 2013 , http: //www.radikal.com.tr/yazarlar/guven_sak/turkiyede_muhendisler ne_is _ yapiyor- 1116908

Upshaw, L. B. 1995. Building brand identity: A strategy for success in a hostile marketplace. NewYork. 